\title{
Aggressive HIV-I?
}

\section{Ben Berkhout*, Anthony de Ronde and Lia van der Hoek}

\author{
Address: Department of Human Retrovirology, Academic Medical Center, University of Amsterdam, Meibergdreef 15, 1105 AZ Amsterdam, the \\ Netherlands \\ Email: Ben Berkhout* - b.berkhout@amc.uva.nl; Anthony de Ronde -ronde@amc.uva.nl; Lia van der Hoek - c.m.vanderhoek@amc.uva.nl \\ * Corresponding author
}

Published: 28 February 2005

Retrovirology 2005, 2:13 doi:10.1186/1742-4690-2-13

This article is available from: http://www.retrovirology.com/content/2/1/13

(C) 2005 Berkhout et al; licensee BioMed Central Ltd.

This is an Open Access article distributed under the terms of the Creative Commons Attribution License (http://creativecommons.org/licenses/by/2.0), which permits unrestricted use, distribution, and reproduction in any medium, provided the original work is properly cited.
Received: 25 February 2005

Accepted: 28 February 2005

\begin{abstract}
New York City health officials announced on February I I, 2005 that a patient rapidly developed full-blown AIDS shortly after being diagnosed with a rare, drug-resistant strain of HIV-I. The New York City Department of Health issued an alert to all hospitals and doctors and a press conference was held to announce the emergence of an aggressive HIV-I strain that may be difficult to treat and that appears to trigger rapid progression to AIDS. Is the panic justified?
\end{abstract}

The two phenomena of rapid disease progression and multi-drug resistance, which are combined in the aggressive HIV-1 strain, are not unique. HIV-1 causes a persistent infection and this virus is generally not a fast killer. Within the Amsterdam Cohort Studies on HIV-AIDS, it takes on average 8.3 years from the time a person is first infected with HIV-1 for AIDS to develop, and another 17 months from AIDS to death [1]. However, the length of the incubation period varies from 2 months to more than 20 years. Cases where it takes much shorter are not uncommon (rapid-progressors), and likewise there is a significant group of socalled long-term non-progressors [2-5]. There seems uncertainty about the actual date of infection of the New York individual, such that AIDS may actually not have developed within 2 to 3 months, but rather within 20 months, which makes this case less exotic. Transmission of a drug-resistant HIV-1 variant is not uncommon either $[6,7]$. The number of cases have remained relatively small, but may be on the rise due to an increase in therapy failures [8]. The New York virus appeared resistant to three classes of antivirals (the Reverse Transcriptase inhibitors; nucleoside and nonnucleoside drugs, as well as Protease inhibitors), but this is not unexpected either in the era of combination-therapy in which therapy failure will usually mean the emergence of multi-drug resistant HIV-1 variants.

Drug-resistant HIV-1 variants usually have reduced replication capacity compared to a wild-type virus due to the mutations in the Reverse Transcriptase and Protease enzymes [9]. This loss in replication fitness may be even larger for a multi-drug resistant virus [10]. How does this relate to the aggressive disease course? More research is needed to resolve this issue. First, it is not always true that the acquisition of drug-resistance mutations causes a fitness loss. Even in case a loss is apparent, the virus may select compensatory changes over time, and the end result may in fact be a virus variant with increased replication fitness [11]. Second, one can only link a particular pathogenicity phenotype to a virus strain when a distinct disease pattern is seen in multiple infected persons. When an isolated case is discussed, it is equally possible that the particular disease pattern is not due to the virus, but rather due to a special property of the infected human host. Person-to-person variation in the immune system or other factors that interact with HIV-1 (receptors, innate immune factors etc) can greatly influence disease progression [12]. 
Overall, this case seems relatively rare but not necessarily alarming. Increased attention is not necessarily bad, but press conferences should be reserved for situations when a cluster of such transmissions is apparent. The current hype about super aggressive HIV-1 strains seems unfounded.

\section{Competing interests}

The author(s) declare that they have no competing interests

\section{References}

I. Veugelers PJ, Schechter MT, Tindall B, Moss AR, Page KA, Craib KJ, Cooper DA, Coutinho RA, Charlebois E, Winkelstein W Jr: Differences in time from HIV seroconversion to CD4+ lymphocyte end-points and AIDS in cohorts of homosexual men. AIDS 1993, 7:1325-1329.

2. Klein MR, van Baalen CA, Holwerda AM, Kerkhof G Sr, Bende RJ, Keet IP, Eeftinck-Schattenkerk JK, Osterhaus AD, Schuitemaker H, Miedema F: Kinetics of Gag-specific cytotoxic T lymphocyte responses during the clinical course of HIV-I infection: a longitudinal analysis of rapid progressors and long-term asymptomatics. J Exp Med 1995, I 81: I 365-1372.

3. Hogervorst $E$, Jurriaans $S$, de Wolf $F$, van Wijk A, Wiersma A, Valk M, Roos M, van Gemen B, Coutinho R, Miedema F, Goudsmit ]: Predictors for non- and slow progression in human immunodeficiency virus (HIV) type I infection: low viral RNA copy numbers in serum and maintenance of high HIV-I p24-specific but not V3-specific antibody levels. J Infect Dis 1995, | $71: 8||-82 \mid$.

4. Keet IP, Krijnen P, Koot M, Lange JM, Miedema F, Goudsmit J, Coutinho RA: Predictors of rapid progression to AIDS in HIVI seroconverters. AIDS 1993, 7:5|-57.

5. Keet IP, Veugelers PJ, Koot M, de Weerd MH, Roos MT, Miedema F, de Wolf F, Goudsmit J, Coutinho RA: Temporal trends of the natural history of HIV-I infection following seroconversion between 1984 and 1993. AIDS 1996, 10:1601-1602.

6. de Ronde A, van Dooren M, van der Hoek L, Bouwhuis D, de Rooij E, van Gemen B, de Boer R, Goudsmit J: Establishment of new transmissible and drug-sensitive human immunodeficiency virus type I wild types due to transmission of nucleoside analogue-resistant virus. J Virol 200I, 75:595-602.

7. Bezemer D, Jurriaans S, Prins M, van der Hoek L, Prins JM, de Wolf F, Berkhout $B$, Coutinho R, Back NK: Declining trend in transmission of drug-resistant HIV-I in Amsterdam. AIDS 2004, 18:157|-I577.

8. Little SJ, Holte S, Routy IP, Daar ES, Markowitz M, Collier AC, Koup RA, Mellors JW, Connick E, Conway B, Kilbym M, Wang L, Whitcomb JM, Hellmann NS, Richman DD: Antiretroviral-drug resistance among patients recently infected with HIV. N Engl J Med 2002, 347:385-394.

9. Back NKT, Nijhuis M, Keulen W, Boucher CAB, Oude Essink BB, van Kuilenburg ABP, van Gennip AH, Berkhout B: Reduced replication of 3TC-resistant HIV-I variants in primary cells due to a processivity defect of the reverse transcriptase enzyme. $E M B O$ J 1996, I 5:4040-4049.

10. Berkhout B: HIV-I evolution under pressure of protease inhibitors: climbing the stairs of viral fitness. J Biomed Sci 1999, 6:298-305.

II. Nijhuis M, Schuurman R, de Jong D, Erickson J, Gustchina E, Albert J, Schipper P, Gulnik S, Boucher CA: Increased fitness of drug resistant HIV-I protease as a result of acquisition of compensatory mutations during suboptimal therapy. AIDS 1999, I 3:2349-2359.

12. Liu R, Paxton WA, Choe S, Ceradini D, Martin SR, Horuk R, MacDonald ME, Stuhlmann H, Koup RA, Landau NR: Homozygous defect in HIV-I coreceptor accounts for resistance of some multiply-exposed individuals to HIV-I infection. Cell 1996, 86:367-377.

\section{Publish with Biomed Central and every} scientist can read your work free of charge

"BioMed Central will be the most significant development for disseminating the results of biomedical research in our lifetime. "

Sir Paul Nurse, Cancer Research UK

Your research papers will be:

- available free of charge to the entire biomedical community

- peer reviewed and published immediately upon acceptance

- cited in PubMed and archived on PubMed Central

- yours - you keep the copyright
Biomedcentral 